Discussion Paper No. 06-042

\title{
On the Importance of Equity in International Climate Policy: An Empirical Analysis
}

Andreas Lange, Carsten Vogt, and Andreas Ziegler

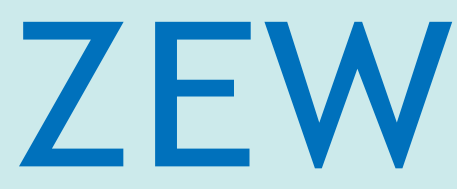

Zentrum für Europäische Wirtschaftsforschung $\mathrm{GmbH}$

Centre for European

Economic Research 
Discussion Paper No. 06-042

\title{
On the Importance of Equity in International Climate Policy: An Empirical Analysis
}

\author{
Andreas Lange, Carsten Vogt, and Andreas Ziegler
}

Download this ZEW Discussion Paper from our ftp server:

ftp://ftp.zew.de/pub/zew-docs/dp/dp06042.pdf

Die Discussion Papers dienen einer möglichst schnellen Verbreitung von neueren Forschungsarbeiten des ZEW. Die Beiträge liegen in alleiniger Verantwortung der Autoren und stellen nicht notwendigerweise die Meinung des ZEW dar.

Discussion Papers are intended to make results of ZEW research promptly available to other economists in order to encourage discussion and suggestions for revisions. The authors are solely responsible for the contents which do not necessarily represent the opinion of the ZEW. 


\section{Non-technical Summary}

Based on unique data from a world-wide survey of agents involved in international climate policy, this paper empirically examines the importance of equity in this field. Our analysis shows that equity issues are considered highly important in international climate negotiations and that the polluter-pays rule (i.e., the rule of equal ratio between abatement costs and emissions) and the accompanying poor losers rule (i.e., the rule of exemption due to GDP) are the most widely accepted equity principles. Using ordinal and (uni- and multivariate) binary probit models we find a strong influence of the economic or emission performance of the agents' country on the importance of equity issues and principles: (i) Equity issues are seen as more important by individuals from G77 countries (including China) or from countries with less current per capita GDP and less future per capita $\mathrm{CO}_{2}$ emissions. (ii) Agents from richer countries are less in favor of incorporating the polluter-pays and the ability-to-pay principle in future international climate agreements. (iii) The poor losers rule is more strongly supported by individuals from G77/China countries or by individuals from countries with less current per capita GDP.

While most of our estimation results are consistent with pure economic self-interest or, in other words, with interests in reducing the cost burdens for the respective countries, the support for the egalitarian principle (i.e., the rule of equal per capita emissions) runs contrary to the hypothesis of economic self-interest: In a short-term time horizon of no more than 20 years no significant effect of the economic performance variables arises while in a long-term time horizon of more than 20 years agents from richer countries are more in favor of incorporating this equity principle. Furthermore, the effect of the economic performance variables on the desired degree of incorporating the polluter-pays principle interestingly becomes less significant in the long-run. Given the idea that equity or fairness arguments can be a basis for international climate agreements if there is a consensus of countries about what is fair, our estimation results indicate that future international climate agreements could possibly be based on a combination of the polluter-pays, the egalitarian, and the poor losers rule. 


\title{
On the Importance of Equity in International Climate Policy: An Empirical Analysis
}

\author{
Andreas Lange ${ }^{a}$, Carsten Vogt ${ }^{b}$, and Andreas Ziegler ${ }^{c}$ \\ a University of Maryland, AREC, 2200 Symons Hall, College Park, MD 20742, USA, E-Mail: alange@ \\ arec.umd.edu, Phone: +1/301/405-1918, Fax: +1/301-314-9091, and \\ Centre for European Economic Research (ZEW) \\ b Leipzig University of Applied Sciences, P.O. Box 301166, 04251 Leipzig, Germany, E-Mail: vogt@ \\ wiwi.htwk-leipzig.de \\ c Corresponding author, Centre for European Economic Research (ZEW), P.O. Box 103443, 68034 Mannheim, \\ Germany, E-Mail: ziegler@zew.de, Phone: +49/621/1235-219, Fax: +49/621/1235-226
}

June 2006

\begin{abstract}
Based on unique data from a world-wide survey of agents involved in international climate policy, this paper empirically analyzes the importance of equity in this field. We find that equity issues are considered highly important in international climate negotiations and that the polluter-pays rule and the accompanying poor losers rule are the most widely accepted equity principles. Our econometric analysis shows a strong influence of the economic or emission performance of the agents' country on the importance of equity issues and principles: (i) Equity issues are seen as more important by individuals from G77/China countries or from countries with less current per capita GDP and less future per capita $\mathrm{CO}_{2}$ emissions. (ii) Agents from richer countries are less in favor of incorporating the polluter-pays and the ability-to-pay principle in future international climate agreements. (iii) The poor losers rule is more strongly supported by individuals from G77/China countries or by individuals from countries with less current per capita GDP. While these results are consistent with pure economic self-interest, the support for the egalitarian principle runs contrary to economic intuition: In the long-run, agents from richer countries are more in favor of incorporating the egalitarian principle. Furthermore, the effect of the economic performance variables on the desired degree of incorporating the polluter-pays principle interestingly becomes less significant in the long-run. This indicates that future international climate agreements could possibly be based on a combination of the polluter-pays, the egalitarian, and the poor losers rule.
\end{abstract}

\section{Keywords}

International Climate Policy, International Environmental Negotiations, Equity Issues, Probit Models

JEL

Q54, Q48, D63, H41 
Equity: "Etymology: ... from Latin aequitat-, aequitas, from aequus equal, fair" "justice according to natural law or right; specifically: freedom from bias or favoritism" (Merriam-Webster Online Dictionary)

\section{Introduction}

Solving social dilemmas as they arise in the provision of public goods or the management of common resources frequently requires voluntary cooperation among the parties involved. While economists have often concentrated on the question of efficiency and analyzed mechanisms to obtain optimal provision levels, they have given less attention to the notion of distributive fairness or equity. This is different in the political arena: In a world where no single party will provide the common good in sufficient quantity and no institution exists to enforce cooperation, an agreement will only be accepted by the parties if it is perceived to be fair. The international negotiations on the mitigation of climate change are one prominent example. Already a quick glance at international climate policy indicates a vital role of equity as the UN Framework Convention on Climate Change recognizes the principle of "common but differentiated responsibilities and respective capabilities”. A look at statements by agents from different countries shows that some of them are concerned with equity issues. Notions like “equal per capita emissions”, “polluter-pays”, or "sovereignty” all stem from specific views on equity.

Cazorla and Toman (2001), Ringius et al. (2002), Najama et al. (2003), and others study the role of equity issues and fairness in international climate policy. The link between equity interest and the prospects of international cooperation is explored by Lange and Vogt (2003) and Lange (2006). They show that equity preferences of the different negotiating parties can increase cooperation rates compared with the relatively pessimistic predictions from traditional economic models of coalition formation (Barrett, 1992, 1994; Carraro and Siniscalco, 1993; Hoel, 1993). Similarly, Ringius et al. (2002) state that "notions of fairness can provide a basis for an international regime only if there is a certain minimum of consensus among its members about what is fair and what is unfair”. In identifying several equity rules which are frequently used in international climate policy, they conclude that there is limited empirical research on which principles are widely accepted and why they play a role in the climate negotiations. Based on unique data from a world-wide survey of agents involved in international climate policy, our paper attempts to close this gap in the literature. We analyze the importance of equity issues in general as well as the importance of different equity rules. 
Our empirical analysis shows that equity issues are considered highly important in international climate negotiations and that the polluter-pays rule (i.e., the rule of equal ratio between abatement costs and emissions) and the accompanying poor losers rule (i.e., the rule of exemption due to GDP) are the most widely accepted equity principles. Using ordinal and (uni- and multivariate) binary probit models we find a strong influence of the economic or emission performance of the agents' country on the importance of equity issues and principles: Equity issues are seen as more important by individuals from G77 countries (including China) or from countries with less current per capita GDP and less future per capita $\mathrm{CO}_{2}$ emissions. Furthermore, agents from richer countries are less in favor of incorporating the polluter-pays and the ability-to-pay principle in future international climate agreements. Finally, the poor losers rule is more strongly supported by individuals from G77/China countries or by individuals from countries with less current per capita GDP.

While these results are consistent with pure economic self-interest, the support for the egalitarian principle (i.e., the rule of equal per capita emissions) runs contrary to economic intuition: In a short-term time horizon of no more than 20 years no significant effect of the economic performance variables arises while in a long-term time horizon of more than 20 years agents from richer countries are even more in favor of incorporating this equity principle. Furthermore, the effect of the economic performance variables on the desired degree of incorporating the polluter-pays principle interestingly becomes less significant in the long-run. This indicates that future international climate agreements could possibly be based on a combination of the polluter-pays, the egalitarian, and the poor losers rule.

The rest of the paper is organized as follows: Section 2 gives an outline of equity issues and principles in international climate policy. In section 3, the data and the variables for the empirical analysis are described. Section 4 discusses the results and section 5 concludes.

\section{Equity issues and principles in international climate policy}

The frequent use of equity arguments in international environmental negotiations could, at first glance, seem puzzling to economists who usually assume that agents are exclusively concerned with the economic costs and benefits of the respective country. According to Ringius et al. (2002), equity issues can enter the negotiation position in different ways: As a preference as actors might dislike being treated or treating others unfairly, as constraints on the substantiation of bargaining positions, or as guidance when the economic consequences are uncertain. 
The nature of the climate change problem allows decomposing policy decisions into those on the climate target (i.e., the aggregate greenhouse gas emission reductions) and those on the distribution of cost burdens which is crucial in evaluating the equity consequences of any given proposal. While the strength of the climate target is certainly a major criterion for the acceptability of any future international climate agreement, negotiations in the past centered to a large extent around questions on how the burdens of some global abatement effort should be distributed. For example, developing countries as well as environmental interest groups in industrialized countries claim that developed countries with high per capita greenhouse gas emissions are responsible for global warming and must take the lead in combating climate change. As a consequence, weaker obligations or complete exemptions of developing countries from emission reduction targets can be based on equity arguments. Another dimension of equity issues is concerned with a fair distribution of burdens among countries with comparable per capita GDP and industry structure. Here, often similar reduction targets are seen as fair: Some proposals during the international climate negotiations allocated emission reduction targets based on present or recent emission levels (Raymond, 2003).

Several studies identify different typologies of equity principles. Rose et al. (1998) distinguish allocation-based, outcome-based, and process-based criteria. In this paper we concentrate on allocation- and outcome-based criteria. Recognizing that most of the criteria can be further specified and thereby subdivided, we follow Ringius et al. (2002) in that we concentrate on main equity principles which dominate the political and the academic debate on international climate policy:

- The egalitarian rule: This rule incorporates the principle of equal per capita emissions. It implies that a country whose population amounts to $\mathrm{x} \%$ of the global population should get $\mathrm{x} \%$ of the global entitlements for greenhouse gas emissions.

- The sovereignty rule: This rule incorporates the principle of equal percentage reduction of current emissions. It implies that a country whose greenhouse gas emissions amount to $\mathrm{x} \%$ of the global greenhouse gas emissions should get $\mathrm{x} \%$ of the global entitlements for greenhouse gas emissions.

- The polluter-pays rule: This rule incorporates the principle of equal ratio between abatement costs and emissions. It implies that a country whose greenhouse gas emissions amount to $\mathrm{x} \%$ of the global emissions should bear $\mathrm{x} \%$ of the global abatement costs for reductions of greenhouse gas emissions. 
- The ability-to-pay rule: This rule incorporates the principle of equal ratio between abatement costs and GDP. It implies that a country whose GDP amounts to $\mathrm{x} \%$ of global gross product should bear $\mathrm{x} \%$ of the global abatement costs for reductions of greenhouse gas emissions.

Besides these main equity rules there are often two further, accompanying principles discussed, namely (as we call them) the poor losers rule and the stand alone criterion:

- The poor losers rule can be seen as a principle of exemption due to GDP. It states that a poor country is exempted from any obligation for greenhouse gas emission reductions until a certain level of GDP per capita compared with the respective average of developed countries is reached.

- The stand alone rule can be seen as a principle of no excessive emission entitlements. It states that the entitlements for greenhouse gas emissions of a country are not higher than its business-as-usual greenhouse gas emissions.

Obviously, the view on the importance of equity issues and the desired incorporation of certain equity principles in international climate policy can differ across people and countries for several reasons. The use of specific equity arguments can be strategically motivated, for example, to avoid or weaken binding emission reduction targets for the individual's country. In this case, equity arguments do not come into play because of an intrinsic real fairness orientation but rather because of pure economic self-interest. In particular, the egalitarian and polluter-pays rules also serve the self-interest of developing countries as they have low per capita emissions and a much smaller historical aggregate of emissions. Similarly, individuals from poor countries could use the ability-to-pay and poor losers principles in their economic self-interest. For such countries it is therefore hard or even impossible to disentangle equity arguments from self-interest unless they support other equity principles as well. The use of the sovereignty rule could be serving the economic self-interest to refuse stricter emission reduction targets than other negotiation parties are willing to accept.

Equity arguments could further be used as a means to facilitate negotiations. The idea behind this might be that equity principles may serve as focal points (Schelling, 1960) which reduce negotiation costs. This argument might gain particular importance in international climate policy as a true assessment of costs and benefits seems impossible due to the large uncertainties and the long-term nature of the climate change problem. 
Finally, fairness considerations of the public in the individual's country could also play a more direct role for the use of specific equity arguments. As international climate negotiations are (sometimes) highly recognized by the public at home, a government that is interested in re-election has to, at least to some degree, take voters' preferences into account. Hence, national voters' preferences may indirectly influence the outcome of international climate negotiations (for a more detailed discussion see Congleton, 1992; Vogt, 2002; Lange and Vogt, 2003; Böhringer and Vogt, 2004).

In this paper we empirically analyze the importance of equity in international climate policy. We explicitly consider the desired degree of incorporation of the different equity rules which have been described above. These views of agents involved in international climate policy are then interacted with characteristics of the agents' countries of origin. Based on economic selfinterest, individuals from less developed (poorer) countries are predicted to be more likely to use equity principles like egalitarian, polluter-pays, ability-to-pay, and poor losers as the application of all of them reduces the financial burdens on their countries.

The importance of the respective equity rule may also change over time. While a strict application of a single rule (e.g., the egalitarian principle) can involve huge wealth transfers and thereby prohibitively high costs for industrialized countries in the short-run, the use of the same rule might get feasible in the long-run. In this vein, prominent proposals like "contraction and convergence" combine different equity principles and shift their respective weight as a function of time. Therefore, we also analyze the stated degree of incorporation of the equity rules in international climate policy in the short-term and long-term time horizon.

\section{Data and variables}

The data for our empirical analysis stem from a world-wide survey which was carried out with the help of a standardized questionnaire and which was sent in 2004 via e-mail to 1695 agents involved in climate policy. The e-mail addresses of the agents were taken from official UN documents available on the Internet such as from different climate policy and IPCC workshops. The participants obtained an individual login and password for an Internet questionnaire. This procedure of sending out passwords allowed us to control the access to the survey and, in particular, ensured that each participant could fill out the questionnaire only once. Alternatively, the participants could fill out a Word-document or PDF and send it back via e-mail or postal mail. 
Our empirical analysis is based on the data of the first part of the questionnaire in which we study the personal views on equity. ${ }^{1}$ After explaining the six equity rules (see previous section), agents were first surveyed on the importance of equity issues in international climate policy (we differentiate between "Very high importance”, "High importance”, “Moderate importance”, "Low importance”, and “No importance”). We derive a corresponding ordinal variable "Importance" which comprises integers from one to four for our empirical analysis whereby the value four designates "Very high importance" and the value one designates "Low importance” or "No importance”. We also consider two dummy variables "Very high importance" and "Very high or high importance" derived from this ordinal variable regarding the importance of equity issues in international climate negotiations.

Second we asked which of the four main equity rules "Egalitarian”, "Sovereignty”, "Polluterpays”, or "Ability-to-pay” comes nearest to the personal definition of equity in international climate negotiations. Furthermore, we asked whether "Poor losers" and "Stand alone" should be applied as accompanying rules besides the main equity rules.

Third we asked for each of the six equity rules to which degree it should be incorporated in any future international climate agreement (we differentiate between "Very high degree", “High degree”, “Moderate degree”, “Low degree”, and “No degree”). We also differentiate between the consideration of a short-term time horizon of no more than 20 years and the consideration of a long-term time horizon of more than 20 years concerning the desired degree of incorporation of the equity principles. For both time horizons, we derive a corresponding ordinal variable "Degree" which comprises integers from one to five whereby the value five designates "Very high degree" and the value one designates "No degree". We also consider two dummy variables "Very high degree" and "Very high or high degree" derived from this ordinal variable.

Finally, the questionnaire contains some questions about the individual's background. In particular, we surveyed the nationality, but furthermore also the participation in a Conference of the Parties (COP) or a meeting of the subsidiary bodies, the field of the highest educational degree or training, the age, the gender, and the type of organization the agents work for. The individual nationality is the basis for variables of the economic and environmental (regarding future per capita $\mathrm{CO}_{2}$ emissions) performance of the respondent's country. For international

\footnotetext{
${ }^{1}$ The questionnaire consists of two parts. While the first part addresses the individual views on equity, the second part studies the perceptions on the equity views of different countries or groups of countries that play an important role in international climate negotiations. By addressing the views on countries' positions, the second part methodologically differs from the first part. We therefore leave the analysis of the corresponding data to future research.
} 
climate policy perhaps most important is the difference between the group of 77 countries (including China) and other countries. Therefore, the dummy variable "G77/China” takes the value one if the respondent's nationality is from these countries. However, to better account for the economic or emission performance of countries, we consider two additional variables in our empirical analysis. The variable "GDP per capita” denotes for each respondent the last available per capita GDP (in ten thousand \$) of the respective country of origin from the Penn World Table (Heston et al., 2002) since 1995 (most data stem from 2000). The variable " $\mathrm{CO}_{2}$ per capita” denotes for each respondent the projections of the per capita $\mathrm{CO}_{2}$ emissions of the respective country in 2010. These future emission levels (for groups of countries) are based on the worldwide energy model POLES (Criqui et al., 1996; Criqui, 2001). In the econometric analysis we only include one of these three economic and emission performance variables due to the strong correlations between "G77/China", "GDP per capita", and " $\mathrm{CO}_{2}$ per capita" which can lead to multicollinearity problems. Furthermore, we do not only analyze the per capita GDP of the respective country but also the corresponding total GDP (“GDP”) (in one trillion \$). This control variable can be interpreted as a mixture of the economic performance and size of the respondents' countries.

Concerning the other aforementioned questions about the individual background, the dummy variable "COP" takes the value one if the respondent participated in a COP or a meeting of the subsidiary bodies. Regarding the educational degree, we make a distinction between social scientists and others. The dummy variable "Social science" takes the value one if the respondent's highest degree or training is in political sciences, economic/business administration, or law. ${ }^{2}$ The dummy variable "Gender" takes the value one if the respondent is female. ${ }^{3}$ Finally, the dummy variable "NGO" takes the value one if the respondent works for environmental or non-environmental NGO and the variable "Age" denotes the natural logarithm of the respondent's age (in years).

The summary statistics for the basic explanatory variables which are used in our econometric analysis are reported in Table 1. It should be noted that although 230 out of the 1695 contacted persons participated in the survey, some of the participants did not answer all questions. As a consequence, the number of observations in the empirical analysis is smaller.

\footnotetext{
2 The individual educational background could potentially influence the view on equity. Studies from experimental economics and psychology indicate differences in (cooperative) behavior between economists and non-economists. Marwell and Ames (1981) are among the first that report significant behavioral differences between economists and non-economists, many following studies confirmed their results (e.g., Carter and Irons, 1991; Frank et al., 1993, 1996).

${ }^{3}$ Gender effects are often seen as a determinant of social behavior. In the experimental economics literature, a gender effect has, for example, been observed by Eckel and Grossman (1996a, 1996b).
} 
Table 1 shows, for example, that almost half of the respondents come from G77/China countries. Furthermore, about two thirds of the respondents have participated in a COP or a meeting of the subsidiary bodies and about one fifth of the respondents are female. Regarding the variable “Age” the mean in Table 1 corresponds to an average age of 45.7 years amongst the 183 respondents.

\section{Results}

\subsection{The general importance of equity issues in international climate negotiations}

We start analyzing the general importance of equity issues in international climate negotiations. Table 2 reports the absolute and relative frequencies of answers for all respondents as well as distinguished between respondents from G77/China countries and those from other countries. More than $90 \%$ of respondents state at least a moderate importance, independently of the respondent's country of origin. However, the frequencies for "Very high importance" strongly differ between individuals from G77/China countries (52.38\%) and other countries (26\%). In other words, respondents from G77/China countries emphasize the very high importance of equity issues to a clearly larger extent than respondents from other countries. However, the relative frequencies for "Very high or high importance” do not strongly differ between agents from G77/China countries (78.57\%) and agents from other countries (73.00\%).

Evidence for these results can also be found in Table 3 which reports the correlation coefficients between the stated importance of equity issues in international climate negotiations and nationality: The positive correlation coefficient between "G77/China" and "Very high importance" is rather high and different from zero at all common levels of significance compared with the correlation coefficient between "G77/China" and "Very high or high importance” which is not different from zero even at the $10 \%$ level of significance. Table 3 additionally considers the ordinal variable "Importance” (in this respect, Spearman's rank correlation coefficient is applied) and the economic and emission performance variables “GDP per capita” and “ $\mathrm{CO}_{2}$ per capita”. According to this, the poorer the individual's country of origin or the less the per capita $\mathrm{CO}_{2}$ emissions, the higher is the stated importance of equity issues (particularly regarding a very high importance) in international climate policy.

To provide further insights and to examine whether there are real effects or only relationships, we econometrically analyze the determinants of the stated importance of equity issues in 
international climate negotiations importance with binary and ordinal probit models. ${ }^{4}$ Table 4 reports the estimation results in different ordinal probit models with the dependent variable "Importance” as described above. According to this, "G77/China” has a strong positive and "GDP per capita" and " $\mathrm{CO}_{2}$ per capita” have a strong negative effect at the $1 \%$ level of significance when "GDP” is not included as control variable in probit models (1), (2), and (3). When "GDP” is included as control variable in probit models (4), (5), and (6), the effect of these economic or emission performance variables is weaker, potentially due to multicollinearity problems since "GDP" is strongly correlated with the economic and emission performance variables. However, the influence holds at the $10 \%$ level of significance for "GDP per capita” and even at the 5\% level of significance for "G77/China" and “ $\mathrm{CO}_{2}$ per capita”. Interestingly, neither "Social science” nor "Gender" or "NGO" have any significant effect, whereas the agent's age has a positive effect on the importance of equity mostly at the $5 \%$ level of significance (and "COP” a weakly significantly negative influence in two probit models).

We complement this analysis by considering the estimation results in different binary probit models in Table 5. The dependent variable is the dummy variable "Very high importance" as aforementioned. These estimation results widely confirm the corresponding main results in the ordinal probit model in Table 4: "G77/China” has a strong positive and "GDP per capita" and " $\mathrm{CO}_{2}$ per capita” have a strong negative effect mostly at the $1 \%$ level of significance even when "GDP" is included as control variable. ${ }^{5}$

\subsection{The incorporation of equity rules in future international climate agreements}

After studying the general importance of equity issues, we now analyze what agents involved in international climate policy associate with the notion of equity. Table 6 reports which of the four main equity rules (egalitarian, sovereignty, polluter-pays, or ability-to-pay) comes nearest to the personal definition of equity in international climate negotiations. Table 7 reports the desired application of the accompanying equity rules (poor losers and stand alone) in international climate negotiations.

\footnotetext{
${ }^{4}$ The corresponding maximum likelihood estimations (as well as the descriptive statistics discussed above) have been performed with the software package STATA. In doing so, the so-called robust estimations of the standard deviation of the parameter estimates (White, 1982) are considered to calculate the z-statistics (for details see the STATA handbooks).

${ }^{5}$ We have also analyzed the determinants of "very high or high importance" in a binary probit model (the estimation results are available upon request). Consistently with the descriptive statistics in Table 3, only " $\mathrm{CO}_{2}$ per capita” has a weakly significantly negative effect.
} 
According to Table 7, the poor losers principle is more attractive than the stand alone criterion. While $52 \%$ of the respondents state an application of the stand alone rule, the corresponding relative frequency for the poor losers rule is over 85\%. ${ }^{6}$ Table 6 shows that almost half of the respondents state that the polluter-pays rule comes nearest to their personal definition of equity in international climate negotiations, followed by the egalitarian rule (22.70\%) and the ability-to-pay rule (20\%). Surprisingly, only $7.57 \%$ of the respondents state that the sovereignty principle comes nearest to their personal definition of equity. Although this principle is not perceived as an appropriate equity or fairness rule, its frequent use in international environmental agreements could potentially be explained by its relatively easy implementation: Emission data are usually better available than estimates of abatement costs. This equity rule could therefore serve as a proxy of the desired polluter-pays rule. The more a country emits, the larger are the required reductions and thus, approximately, the share of costs this country has to bear.

Table 6 shows differences in the acceptance of the respective equity rules due to the respondent's country: ${ }^{7}$ Compared with respondents from other countries, respondents from G77/China countries put even more emphasis on the polluter-pays rule (56.47\% vs. 44\%) and less on the egalitarian rule (17.65\% vs. $27 \%)$. The weaker acceptance of the egalitarian rule may seem surprising as the comparisons of per capita emissions are frequently stressed by delegates from developing countries. However, the acceptance of the egalitarian, the polluterpays, and the ability-to-pay rules are in line with economic self-interest as long as the individual's country is poor and has small per capita emissions. Similar to the discussion on the sovereignty principle, it is therefore possible that the allocation-based egalitarian rule is stressed in international climate negotiations because it is easier to implement than outcomebased criteria.

We now complement the analysis of the equity rules with the consideration of the desired degree of incorporation of each equity principle in any future international climate agreement in both a short-term time horizon of no more than 20 years and a long-term time horizon of more than 20 years. Table 8 reports the corresponding absolute and relative frequencies. In accordance with the results in Table 6, the polluter-pays rule is also most attractive amongst

\footnotetext{
${ }^{6}$ It is remarkable that the relative frequencies for agents from G77/China countries and for agents from other countries are nearly identical for each accompanying equity principle.

7 We have also performed an analysis with multinomial logit models regarding the determinants of the acceptance of these four main equity rules (the estimation results are available upon request). This econometric analysis shows a weakly positive influence significant influence of "GDP per capita” (but not of " $\mathrm{CO}_{2}$ per capita”, and in contrast to the results in Table 6 not of "G77/China”) on the acceptance of the egalitarian principle, however, only compared with the acceptance of the polluter-pays principle.
} 
all main equity rules regarding the degree of incorporation in any future international climate agreement, independently of the time horizon. There is virtually no difference between the attractiveness of the egalitarian and the sovereignty rule in the short term. However, the desired degree of incorporating the egalitarian rule strongly increases in a long-term time horizon (regarding the relative frequencies for "Very high degree" from $11.96 \%$ to $23.78 \%$ and for "High degree" from $18.48 \%$ to $29.73 \%$ ). As in Table 7 , the poor losers rule is considered an important accompanying equity principle. The support for this rule, however, decreases in a long-term time horizon (for "Very high degree" from $41.30 \%$ to $27.96 \%$ ).

The results in Table 8 suggest an interesting comparison with the prominent approach of "contraction and convergence" in defining the allocation of abatement burdens across countries. This approach would combine the sovereignty rule (similar in consequences to the polluter-pays rule) in the short-run with the egalitarian rule in the long-run. The tendency of the results in Table 8 indicates that such an approach, in particular combined with the poor losers rule in the short-run, could gain support for future international climate policy.

To provide further insights, we econometrically analyze the desired degree of incorporation of the respective equity principles with different ordinal probit models considering the dummy variable "Degree" as dependent variable for each equity rule. Tables 9 and 10 (for a shortterm time horizon) and Tables 11 and 12 (for a long-term time horizon) report the corresponding estimation results. The tables report the estimation results in probit models which include the economic performance variables "G77/China” and "GDP per capita”. The corresponding estimation results with the emission performance variable " $\mathrm{CO}_{2}$ per capita" are available upon request.

Regarding these economic performance variables in a short-term time horizon, Tables 9 and 10 show that "G77/China" has a positive effect on the degree of incorporation of the poor losers rule and "GDP per capita" a negative effect on the degree of incorporation of the polluter-pays and the poor losers rules at the $5 \%$ level of significance, respectively. These estimation results and also the significantly negative effect of "G77/China” on the degree of incorporation of the sovereignty rule are consistent with pure economic self-interest. Regarding a long-term time horizon, the estimation results in Tables 11 and 12 further support the hypothesis of economic self-interest. These tables show that "GDP per capita" has a strongly significantly negative effect (or, alternatively, “G77/China” has a significantly positive effect) on the desired degree of incorporation of the poor losers rule and a less robust 
negative influence on the desired degree of incorporation of the ability-to-pay, the polluterpays, or the stand alone rule.

However, the economic performance variables have no significant influence on the degree of incorporation of the egalitarian rule in the short-run and, contrary to economic intuition, "G77/China” even has (in accordance with the descriptive statistics in Table 6) a negative influence at the $5 \%$ level of significance in the long-run. This points to the possibility that the personal perception of equity issues in international climate policy may not be exclusively determined by economic self-interest, but can also be influenced by real fairness considerations since non-G77/China countries do not benefit from the incorporation of the egalitarian rule in any future international climate agreement. Furthermore, the effect of the economic performance variables on the desired degree of incorporating the polluter-pays (and also the sovereignty principle) interestingly becomes less significant in the long-run. This indicates that future international climate agreements could possibly be based on a combination of the polluter-pays, the egalitarian, and the poor losers rules.

To complete the analysis, it should be noted that the control variables "COP” and "Gender" have no significant effect on the desired degree of incorporation of any equity rule. "Social science" has a significantly negative influence on the degree of incorporation of the sovereignty rule in a long-term time horizon. In contrast, "NGO” has a strongly significantly positive influence on the degree of incorporation of the polluter-pays principle and a less robust negative influence on the degree of incorporation of the poor losers rule in a short-term time horizon. Finally, both in the short-run and in the long-run "Age” has a significantly negative effect on the degree of incorporation of the poor losers rule and (at higher levels of significance, respectively) of the stand alone rule.

In further investigations we have (in accordance with the analysis of the general importance of equity issues as discussed above) also analyzed different binary probit models (with the dependent variables "Very high degree” or "Very high or high degree”) regarding the determinants of the desired degree of incorporation of equity rules in future international agreements (in both a short-term and long-term time horizon). In this respect, we have applied standard univariate probit models, but also (as a robustness check) multivariate probit models. ${ }^{8}$ The estimation results from the binary probit analysis (not displayed in this paper for

\footnotetext{
${ }^{8}$ With the multivariate probit models we can account for the positive correlations between the equity rules regarding the desired degree of incorporation in future international agreements. However, the multivariate probit estimation with, for example, the four main equity rules is computationally difficult due to the occurrence of multiple integrals. We therefore have incorporated a simulation methods (i.e., the GHK simulator, see the STATA handbooks) in the maximum likelihood estimation.
} 
brevity due to the enormous extent of the different estimation results, but available upon request) further strengthen the corresponding main estimation results from the ordinal probit analysis.

\section{Summary and conclusions}

In this paper we empirically analyzed the importance of equity in international climate policy. Based on unique data from a world-wide survey of agents involved in international climate policy, we find that equity issues are considered highly important in international climate negotiations and that the polluter-pays rule and the accompanying poor losers rule are the most widely accepted equity principles.

Our econometric analysis with ordinal and (uni- and multivariate) binary probit models shows a strong influence of the economic or emission performance of the agents' country on the importance of equity issues and principles:

- Equity issues are seen as more important by individuals from G77/China countries or from countries with less current per capita GDP and less future per capita $\mathrm{CO}_{2}$ emissions.

- Agents from richer countries are less in favor of incorporating the polluter-pays and the ability-to-pay principle in future international climate agreements.

- The poor losers rule is more strongly supported by individuals from G77/China countries or by individuals from countries with less current per capita GDP.

These estimation results are consistent with pure economic self-interest or, in other words, with interests in reducing the cost burdens for the respective countries. Therefore, the question arises who would be willing to bear the burdens of international climate policy at all. In this paper, however, we have abstracted from the question of defining the aggregate emission reduction target and instead have focused on equity rules which might determine the burden sharing between countries.

The support for the egalitarian principle runs against economic intuition (i.e., the hypothesis of economic self-interest): In the short-run no significant effect of the economic performance variables arises while agents from richer countries are even more in favor of incorporating this equity principle in the long-run. This points to the possibility that the personal perception of equity issues in international climate policy may not be exclusively determined by economic self-interest, but can also be influenced by real fairness considerations since non- 
G77/China countries do not benefit from the incorporation of the egalitarian rule in any future international climate agreement.

Furthermore, the effect of the economic performance variables on the desired degree of incorporating the polluter-pays principle interestingly becomes less significant in the longrun. Given the idea that equity or fairness arguments can be a basis for international climate agreements if there is a consensus of countries about what is fair, our estimation results indicate that future international climate agreements could possibly be based on a combination of the polluter-pays, the egalitarian, and the poor losers rule. 


\section{References}

Barrett, S. (1992): International environmental agreements as games. In: Pethig, R. (ed.), Conflicts and Cooperation in Managing Environmental Resources. Springer, Berlin, 11-37.

Barrett, S. (1994): Self enforcing international environmental agreements. Oxford Economic Papers 46, 878-894.

Böhringer, C. and C. Vogt (2004): Dismantling of a breakthrough: the Kyoto Protocol as symbolic policy, European Journal of Political Economy 20(3), 597-617.

Carraro, C. and D. Siniscalco (1993): Strategies for the protection of the environment. Journal of Public Economics 52, 309-328.

Carter, J. and M. Irons (1991): Are economists different and if so, why?, Journal of Economic Perspectives 5, 171-177.

Cazorla, M.V. and M.A. Toman (2001): International equity and climate change policy. In: Toman, M.A. (ed.), Climate Change Economics and Policy. Resources for the Future, Washington, 235-247.

Congleton, R.D. (1992): Political institutions and pollution control, Review of Economics and Statistics 74 (3), 412-421.

Criqui, P. (2001): POLES Prospective Outlook on Long-term Energy Systems, Institute of Energy Policy and Economics, Grenoble, France. (http://web.upmf-grenoble.fr/iepe/textes/ POLES8p_01.pdf).

Criqui, P., F. Cattier, P. Menanteau, and M.-C. Quidoz (1996): POLES 2.2. Reference Guide, Institute of Energy Policy and Economics, Grenoble, France.

Eckel, C.C. and P. Grossman (1996a): The relative price of fairness: Gender differences in a punishment game, Journal of Economic Behavior and Organization 30, 143-158.

Eckel, C.C. and P. Grossman (1996b): Are women less selfish than men? Evidence from dictator experiments, discussion paper, Virginia Polytechnic Institute and State University.

Frank, R.H., T. Gilovich, and D.T. Regan (1993): Does studying economics inhibit cooperation?, Journal of Economic Perspectives 7, 159-171.

Frank, R.H., T. Gilovich, and D.T. Regan (1996): Do Economists make bad citizens?, Journal of Economic Perspectives 10, 187-192. 
Heston, A., R. Summers, and B. Aten (2002): Penn World Table Version 6.1, Center for International Comparisons at the University of Pennsylvania (CICUP).

Hoel, M. (1992): International environmental conventions: the case of uniform reductions of emissions. Enviromental and Resource Economics 2, 141-159.

Lange, A. (2006): The Impact of Equity-preferences on the Stability of Heterogeneous International Agreements, Environmental and Resource Economics, forthcoming.

Lange, A. and C. Vogt (2003): Cooperation in International Environmental Negotiations due to a Preference for Equity, Journal of Public Economics 87, 2049-2067.

Marwell, G. and R.E. Ames (1981): Economists free ride, does anyone else? Experiments on the provision of public goods IV, Journal of Public Economics, 15, 295-310.

Najama, A., S. Huq, and Y. Sokona (2003): Climate Negotiations Beyond Kyoto: Developing Countries Concerns and Interests, Climate Policy 3, 221-231.

Raymond, L. (2003): Private rights in public resources - equity and property allocation in market-based environmental policy, Resources for the Future, Washington, DC.

Ringius, L., A. Torvanger, and A. Underdal (2002): Burden sharing and fairness principles in international climate policy, International Environmental Agreements: Politics, Law and Economics 2, 1-22.

Rose, A., B. Stevens, J. Edmonds, and M. Wise (1998): International equity and differentiation in global warming policy, Environmental and Resource Economics 12, 25-51.

Schelling, T. (1960): The strategy of conflict, Harvard University Press, Cambridge, MA.

Vogt, C. (2002): On the Political Economy of International Environmental Agreements Theoretical Considerations and Empirical Evidence, in: Böhringer, C., Finus, M. and C. Vogt, Controlling Global Warming, New Horizons in Environmental Economics, Cheltenham, 178213.

White, H. (1982): Maximum Likelihood Estimation of Misspecified Models, Econometrica 50, 1-25. 


\section{Appendix: Tables}

Table 1: Means and standard deviations of explanatory variables in the econometric analysis

\begin{tabular}{|l|c|c|c|}
\hline & Mean & Standard deviation & $\begin{array}{c}\text { Number of } \\
\text { respondents }\end{array}$ \\
\hline G77/China & 0.46 & 0.50 & 194 \\
\hline GDP per capita & 1.46 & 1.40 & 189 \\
\hline CO 2 per capita & 2.02 & 1.48 & 193 \\
\hline GDP & 1.05 & 2.18 & 193 \\
\hline COP & 0.66 & 0.48 & 181 \\
\hline Social science & 0.18 & 0.39 & 183 \\
\hline Age & 3.80 & 0.24 & 189 \\
\hline Gender & 0.20 & 0.40 & 0.25 \\
\hline NGO & 0.07 & & 194 \\
\hline
\end{tabular}


Table 2: Absolute and relative frequencies concerning the stated importance of equity issues in international climate negotiations

\begin{tabular}{|l|c|c|c|c|c|}
\hline & $\begin{array}{c}\text { Very high } \\
\text { importance }\end{array}$ & $\begin{array}{c}\text { High } \\
\text { importance }\end{array}$ & $\begin{array}{c}\text { Moderate } \\
\text { importance }\end{array}$ & $\begin{array}{c}\text { Low or no } \\
\text { importance }\end{array}$ & Total \\
\hline All & 70 & 69 & 32 & 13 & 184 \\
$38.04 \%$ & $37.50 \%$ & $17.39 \%$ & $7.07 \%$ & $100 \%$ \\
\hline G77/China & 44 & 22 & 13 & 5 & 84 \\
\hline Non- & $52.38 \%$ & $26.19 \%$ & $15.48 \%$ & $5.95 \%$ & $100 \%$ \\
G77/China & 26 & 47 & 19 & 8 & 100 \\
\hline
\end{tabular}

Table 3: Correlation coefficients (p-values) between the stated importance of equity issues in international climate negotiations and the economic or emission performance of the respondent's country of origin

\begin{tabular}{|l|c|c|c|}
\hline & Importance & Very high importance & $\begin{array}{c}\text { Very high or high } \\
\text { importance }\end{array}$ \\
\hline G77/China & $\begin{array}{c}0.22^{* * *} \\
(0.00)\end{array}$ & $\begin{array}{c}0.27^{* * *} \\
(0.00)\end{array}$ & $\begin{array}{c}0.06 \\
(0.41)\end{array}$ \\
\hline GDP per capita & $-0.19^{* * *}$ & $-0.26^{* * *}$ & -0.05 \\
& $(0.01)$ & $(0.00)$ & $(0.47)$ \\
\hline CO $_{2}$ per capita & $-0.22^{* * *}$ & $-0.25^{* * *}$ & $-0.13^{*}$ \\
& $(0.00)$ & $(0.00)$ & $(0.09)$ \\
\hline
\end{tabular}

\section{Notes:}

$* * *(* *, *)$ means that the null hypothesis that the appropriate correlation coefficient is zero can be rejected at the $1 \%(5 \%, 10 \%)$ level of significance (according to the corresponding two-tailed test).

Number of observations varies between 179 and 184 . 
Table 4: Maximum likelihood estimates (z-statistics) in ordered probit models, determinants of the stated importance of equity issues in international climate negotiations, dependent variable:"Importance"

\begin{tabular}{|c|c|c|c|c|c|c|}
\hline $\begin{array}{l}\text { Explanatory } \\
\text { variables }\end{array}$ & (1) & $(2)$ & (3) & (4) & (5) & (6) \\
\hline G77/China & $\begin{array}{l}0.52^{* * *} \\
(2.73)\end{array}$ & $\begin{array}{l}-- \\
--\end{array}$ & $\begin{array}{l}-- \\
--\end{array}$ & $\begin{array}{l}0.42^{* *} \\
(2.10)\end{array}$ & $\begin{array}{l}-- \\
--\end{array}$ & $\begin{array}{l}-- \\
--\end{array}$ \\
\hline GDP per capita & $\begin{array}{l}-- \\
--\end{array}$ & $\begin{array}{l}-0.22^{* * *} \\
(-2.59)\end{array}$ & $\begin{array}{l}-- \\
--\end{array}$ & $\begin{array}{l}-- \\
--\end{array}$ & $\begin{array}{l}-0.18^{*} \\
(-1.82)\end{array}$ & $\begin{array}{l}-- \\
--\end{array}$ \\
\hline $\mathrm{CO}_{2}$ per capita & -- & $\begin{array}{l}-- \\
--\end{array}$ & $\begin{array}{c}-0.20^{* * *} \\
(-3.21)\end{array}$ & $\begin{array}{l}-- \\
--\end{array}$ & $\begin{array}{l}-- \\
-\end{array}$ & $\begin{array}{c}-0.19^{* *} \\
(-2.23)\end{array}$ \\
\hline GDP & -- & $\begin{array}{l}-- \\
--\end{array}$ & $\begin{array}{l}-- \\
--\end{array}$ & $\begin{array}{l}-0.08^{* *} \\
(-2.31)\end{array}$ & $\begin{array}{c}-0.06 \\
(-1.60)\end{array}$ & $\begin{array}{c}-0.03 \\
(-0.71)\end{array}$ \\
\hline COP & $\begin{array}{c}-0.32 \\
(-1.59)\end{array}$ & $\begin{array}{c}-0.31 \\
(-1.52)\end{array}$ & $\begin{array}{c}-0.34^{*} \\
(-1.66)\end{array}$ & $\begin{array}{c}-0.31 \\
(-1.52)\end{array}$ & $\begin{array}{c}-0.30 \\
(-1.47)\end{array}$ & $\begin{array}{c}-0.35^{*} \\
(-1.65)\end{array}$ \\
\hline Social science & $\begin{array}{c}0.23 \\
(0.87)\end{array}$ & $\begin{array}{c}0.26 \\
(0.95)\end{array}$ & $\begin{array}{c}0.34 \\
(1.25)\end{array}$ & $\begin{array}{c}0.35 \\
(1.24)\end{array}$ & $\begin{array}{c}0.34 \\
(1.19)\end{array}$ & $\begin{array}{c}0.39 \\
(1.36)\end{array}$ \\
\hline Age & $\begin{array}{c}0.66^{*} \\
(1.81)\end{array}$ & $\begin{array}{l}0.73^{* *} \\
(1.96)\end{array}$ & $\begin{array}{l}0.76^{* *} \\
(2.10)\end{array}$ & $\begin{array}{l}0.84^{* *} \\
(2.19)\end{array}$ & $\begin{array}{l}0.84^{* *} \\
(2.22)\end{array}$ & $\begin{array}{l}0.90^{* *} \\
(2.36)\end{array}$ \\
\hline Gender & $\begin{array}{l}-0.10 \\
(-0.39)\end{array}$ & $\begin{array}{l}-0.12 \\
(-0.46)\end{array}$ & $\begin{array}{l}-0.08 \\
(-0.32)\end{array}$ & $\begin{array}{l}-0.12 \\
(-0.48)\end{array}$ & $\begin{array}{l}-0.13 \\
(-0.51)\end{array}$ & $\begin{array}{c}-0.08 \\
(-0.31)\end{array}$ \\
\hline NGO & $\begin{array}{c}0.25 \\
(0.52)\end{array}$ & $\begin{array}{c}0.22 \\
(0.47)\end{array}$ & $\begin{array}{c}0.23 \\
(0.48)\end{array}$ & $\begin{array}{c}0.29 \\
(0.62)\end{array}$ & $\begin{array}{c}0.25 \\
(0.56)\end{array}$ & $\begin{array}{c}0.27 \\
(0.56)\end{array}$ \\
\hline
\end{tabular}

Notes:

*** $(* *, *)$ means that the appropriate explanatory variable has an effect at the $1 \%(5 \%, 10 \%)$ level of significance.

Number of observations = 154 in (2), (4), (5), and (6), number of observations = 157 in (1) and (3). 
Table 5: Maximum likelihood estimates (z-statistics) in binary probit models, determinants of the stated importance of equity issues in international climate negotiations, dependent variable: "Very high importance"

\begin{tabular}{|c|c|c|c|c|c|c|}
\hline $\begin{array}{l}\text { Explanatory } \\
\text { variables }\end{array}$ & (1) & $(2)$ & (3) & (4) & (5) & (6) \\
\hline G77/China & $\begin{array}{l}0.77^{* * *} \\
(3.54)\end{array}$ & $\begin{array}{l}-- \\
--\end{array}$ & $\begin{array}{l}-- \\
--\end{array}$ & $\begin{array}{l}0.65^{* * *} \\
(2.88)\end{array}$ & $\begin{array}{l}-- \\
--\end{array}$ & -- \\
\hline GDP per capita & $\begin{array}{l}-- \\
--\end{array}$ & $\begin{array}{l}-0.33^{* * *} \\
(-3.21)\end{array}$ & $\begin{array}{l}-- \\
--\end{array}$ & $\begin{array}{l}-- \\
--\end{array}$ & $\begin{array}{l}-0.27^{* *} \\
(-2.42)\end{array}$ & $\begin{array}{l}-- \\
--\end{array}$ \\
\hline $\mathrm{CO}_{2}$ per capita & $\begin{array}{l}-- \\
--\end{array}$ & $\begin{array}{l}-- \\
--\end{array}$ & $\begin{array}{l}-0.29^{* * * *} \\
(-3.89)\end{array}$ & -- & $\begin{array}{l}-- \\
--\end{array}$ & $\begin{array}{l}-0.25^{* * *} \\
(-2.83)\end{array}$ \\
\hline GDP & $\begin{array}{l}-- \\
--\end{array}$ & $\begin{array}{l}-- \\
--\end{array}$ & $\begin{array}{l}-- \\
--\end{array}$ & $\begin{array}{l}-0.15^{* * *} \\
(-2.78)\end{array}$ & $\begin{array}{l}-0.14^{* *} \\
(-2.22)\end{array}$ & $\begin{array}{c}-0.11 \\
(-1.63)\end{array}$ \\
\hline COP & $\begin{array}{c}-0.41^{*} \\
(-1.83)\end{array}$ & $\begin{array}{l}-0.39^{*} \\
(-1.66)\end{array}$ & $\begin{array}{l}-0.47^{* *} \\
(-2.03)\end{array}$ & $\begin{array}{c}-0.37 \\
(-1.57)\end{array}$ & $\begin{array}{c}-0.37 \\
(-1.54)\end{array}$ & $\begin{array}{l}-0.43^{*} \\
(-1.81)\end{array}$ \\
\hline Social science & $\begin{array}{c}0.37 \\
(1.24)\end{array}$ & $\begin{array}{c}0.40 \\
(1.33)\end{array}$ & $\begin{array}{c}0.50 \\
(1.62)\end{array}$ & $\begin{array}{c}0.53^{*} \\
(1.72)\end{array}$ & $\begin{array}{c}0.52^{*} \\
(1.65)\end{array}$ & $\begin{array}{c}0.57^{*} \\
(1.80)\end{array}$ \\
\hline Age & $\begin{array}{l}1.05^{* *} \\
(2.22)\end{array}$ & $\begin{array}{l}1.06^{* *} \\
(2.22)\end{array}$ & $\begin{array}{l}1.20^{* *} \\
(2.47)\end{array}$ & $\begin{array}{l}1.21^{* *} \\
(2.46)\end{array}$ & $\begin{array}{l}1.19^{* *} \\
(2.46)\end{array}$ & $\begin{array}{l}1.29^{* * *} \\
(2.61)\end{array}$ \\
\hline Gender & $\begin{array}{c}0.14 \\
(0.47)\end{array}$ & $\begin{array}{c}0.09 \\
(0.29)\end{array}$ & $\begin{array}{c}0.15 \\
(0.54)\end{array}$ & $\begin{array}{c}0.08 \\
(0.28)\end{array}$ & $\begin{array}{c}0.06 \\
(0.19)\end{array}$ & $\begin{array}{c}0.13 \\
(0.44)\end{array}$ \\
\hline NGO & $\begin{array}{c}0.28 \\
(0.57)\end{array}$ & $\begin{array}{c}0.18 \\
(0.39)\end{array}$ & $\begin{array}{c}0.27 \\
(0.54)\end{array}$ & $\begin{array}{c}0.29 \\
(0.62)\end{array}$ & $\begin{array}{c}0.21 \\
(0.46)\end{array}$ & $\begin{array}{c}0.28 \\
(0.58)\end{array}$ \\
\hline Constant & $\begin{array}{l}-4.49 \\
(-2.45)\end{array}$ & $\begin{array}{l}-3.66 \\
(-2.00)\end{array}$ & $\begin{array}{l}-4.09 \\
(-2.21)\end{array}$ & $\begin{array}{l}-4.94 \\
(-2.61)\end{array}$ & $\begin{array}{l}-4.15 \\
(-2.23)\end{array}$ & $\begin{array}{l}-4.47 \\
(-2.35)\end{array}$ \\
\hline
\end{tabular}

\section{Notes:}

$* * *(* *, *)$ means that the appropriate explanatory variable has an effect at the $1 \%(5 \%, 10 \%)$ level of significance.

Number of observations = 154 in (2), (4), (5), and (6), number of observations = 157 in (1) and (3). 
Table 6: Absolute and relative frequencies concerning the main equity rules with respect to the personal definition of equity in international climate negotiations

\begin{tabular}{|l|c|c|c|c|c|}
\hline & Egalitarian & Sovereignty & Polluter-pays & Ability-to-pay & Total \\
\hline All & $\begin{array}{c}42 \\
22.70 \%\end{array}$ & $\begin{array}{c}14 \\
7.57 \%\end{array}$ & $\begin{array}{c}92 \\
49.73 \%\end{array}$ & $\begin{array}{c}37 \\
20.00 \%\end{array}$ & $\begin{array}{c}185 \\
100 \%\end{array}$ \\
\hline G77/China & 15 & 6 & 48 & 16 & 85 \\
Non- & $17.65 \%$ & $7.06 \%$ & $56.47 \%$ & $18.82 \%$ & $100 \%$ \\
\hline G77/China & 27 & 8 & 44 & 21 & 118 \\
\hline
\end{tabular}

Table 7: Absolute and relative frequencies concerning the desired application of accompanying equity rules in international climate negotiations

\begin{tabular}{|l|c|c|c|c|c|c|}
\hline & \multicolumn{3}{|c|}{ Poor losers } & \multicolumn{3}{c|}{ Stand alone } \\
\hline & Yes & No & Total & Yes & No & Total \\
\hline All & 157 & 26 & 183 & 78 & 72 & 150 \\
& $85.79 \%$ & $14.21 \%$ & $100 \%$ & $52.00 \%$ & $48.00 \%$ & $100 \%$ \\
\hline G77/China & 72 & 11 & 83 & 35 & 33 & 68 \\
\hline $\begin{array}{l}\text { Non- } \\
\text { G77/China }\end{array}$ & $86.75 \%$ & $13.25 \%$ & $100 \%$ & $51.47 \%$ & $48.53 \%$ & $100 \%$ \\
\hline
\end{tabular}


Table 8: Absolute and relative frequencies concerning the desired degree of incorporation of equity rules in any future international climate agreement

\begin{tabular}{|c|c|c|c|c|c|c|}
\hline \multicolumn{7}{|c|}{ Degree of incorporation in a short-term time horizon of no more than 20 years } \\
\hline Equity rules & $\begin{array}{l}\text { Very high } \\
\text { degree }\end{array}$ & $\begin{array}{l}\text { High } \\
\text { degree }\end{array}$ & $\begin{array}{c}\text { Moderate } \\
\text { degree }\end{array}$ & $\begin{array}{c}\text { Low } \\
\text { degree }\end{array}$ & $\begin{array}{c}\text { No } \\
\text { degree }\end{array}$ & Total \\
\hline \multirow[t]{2}{*}{ Egalitarian } & 22 & 34 & 59 & 42 & 27 & 184 \\
\hline & $11.96 \%$ & $18.48 \%$ & $32.07 \%$ & $22.83 \%$ & $14.67 \%$ & $100 \%$ \\
\hline \multirow[t]{2}{*}{ Sovereignty } & 20 & 36 & 48 & 40 & 39 & 183 \\
\hline & $10.93 \%$ & $19.67 \%$ & $26.23 \%$ & $21.86 \%$ & $21.31 \%$ & $100 \%$ \\
\hline \multirow{2}{*}{$\begin{array}{l}\text { Polluter- } \\
\text { pays }\end{array}$} & 80 & 62 & 26 & 9 & 7 & 184 \\
\hline & $43.48 \%$ & $33.70 \%$ & $14.13 \%$ & $4.89 \%$ & $3.80 \%$ & $100 \%$ \\
\hline \multirow{2}{*}{$\begin{array}{l}\text { Ability- } \\
\text { to-pay }\end{array}$} & 40 & 62 & 43 & 23 & 12 & 180 \\
\hline & $22.22 \%$ & $34.44 \%$ & $23.89 \%$ & $12.78 \%$ & $6.67 \%$ & $100 \%$ \\
\hline \multirow[t]{2}{*}{ Poor losers } & 76 & 52 & 32 & 17 & 7 & 184 \\
\hline & $41.30 \%$ & $28.26 \%$ & $17.39 \%$ & $9.24 \%$ & $3.80 \%$ & $100 \%$ \\
\hline \multirow[t]{2}{*}{ Stand alone } & 19 & 30 & 43 & 34 & 41 & 167 \\
\hline & $11.38 \%$ & $17.96 \%$ & $25.75 \%$ & $20.36 \%$ & $24.55 \%$ & $100 \%$ \\
\hline \multicolumn{7}{|c|}{ Degree of incorporation in a long-term time horizon of more than 20 years } \\
\hline Equity rules & $\begin{array}{l}\text { Very high } \\
\text { degree }\end{array}$ & $\begin{array}{l}\text { High } \\
\text { degree }\end{array}$ & $\begin{array}{c}\text { Moderate } \\
\text { degree }\end{array}$ & $\begin{array}{c}\text { Low } \\
\text { degree }\end{array}$ & $\begin{array}{c}\text { No } \\
\text { degree }\end{array}$ & Total \\
\hline \multirow[t]{2}{*}{ Egalitarian } & 44 & 55 & 46 & 23 & 17 & 185 \\
\hline & $23.78 \%$ & $29.73 \%$ & $24.86 \%$ & $12.43 \%$ & $9.19 \%$ & $100 \%$ \\
\hline \multirow[t]{2}{*}{ Sovereignty } & 24 & 38 & 39 & 41 & 41 & 183 \\
\hline & $13.11 \%$ & $20.77 \%$ & $21.31 \%$ & $22.40 \%$ & $22.40 \%$ & $100 \%$ \\
\hline \multirow{2}{*}{$\begin{array}{l}\text { Polluter- } \\
\text { pays }\end{array}$} & 80 & 65 & 27 & 6 & 9 & 187 \\
\hline & $42.78 \%$ & $34.76 \%$ & $14.44 \%$ & $3.21 \%$ & $4.81 \%$ & $100 \%$ \\
\hline \multirow{2}{*}{$\begin{array}{l}\text { Ability- } \\
\text { to-pay }\end{array}$} & 44 & 52 & 46 & 28 & 14 & 184 \\
\hline & $23.91 \%$ & $28.26 \%$ & $25.00 \%$ & $15.22 \%$ & $7.61 \%$ & $100 \%$ \\
\hline \multirow[t]{2}{*}{ Poor losers } & 52 & 55 & 45 & 23 & 11 & 186 \\
\hline & $27.96 \%$ & $29.57 \%$ & $24.19 \%$ & $12.37 \%$ & $5.91 \%$ & $100 \%$ \\
\hline \multirow[t]{2}{*}{ Stand alone } & 22 & 39 & 34 & 31 & 44 & 170 \\
\hline & $12.94 \%$ & $22.94 \%$ & $20.00 \%$ & $18.24 \%$ & $25.88 \%$ & $100 \%$ \\
\hline
\end{tabular}


Table 9: Maximum likelihood estimates (z-statistics) in ordered probit models, determinants of the desired degree of incorporation of equity rules in future international climate agreements, short-term time horizon, dependent variable: "Degree" (for the egalitarian, the sovereignty, and the polluter-pays rule)

\begin{tabular}{|l|c|c|c|c|c|c|}
\hline & $(1)$ & $(2)$ & $(3)$ & $(4)$ & $(5)$ & $(6)$ \\
$\begin{array}{l}\text { Explanatory } \\
\text { variables }\end{array}$ & Egalitarian & Egalitarian & $\begin{array}{c}\text { Sove- } \\
\text { reignty }\end{array}$ & $\begin{array}{c}\text { Sove- } \\
\text { reignty }\end{array}$ & $\begin{array}{c}\text { Polluter- } \\
\text { pays }\end{array}$ & $\begin{array}{c}\text { Polluter- } \\
\text { pays }\end{array}$ \\
\hline G77/China & $\begin{array}{c}-0.16 \\
(-0.90)\end{array}$ & -- & $\begin{array}{c}-0.36^{* *} \\
(-1.97)\end{array}$ & -- & $\begin{array}{c}0.23 \\
(1.17)\end{array}$ & - \\
\hline GDP per capita & -- & $\begin{array}{c}0.01 \\
(0.18)\end{array}$ & -- & $\begin{array}{c}0.09 \\
(1.17)\end{array}$ & -- & $-0.19^{* *}$ \\
\hline COP & -0.24 & $\begin{array}{c}-0.18 \\
(-1.26)\end{array}$ & $\begin{array}{c}-0.06 \\
(-0.36)\end{array}$ & $\begin{array}{c}0.02 \\
(0.10)\end{array}$ & $\begin{array}{c}-0.05 \\
(-0.25)\end{array}$ & $\begin{array}{c}-0.04 \\
(-0.18)\end{array}$ \\
\hline Social science & $\begin{array}{c}-0.05 \\
(-0.20)\end{array}$ & $\begin{array}{c}-0.05 \\
(-0.20)\end{array}$ & $\begin{array}{c}-0.06 \\
(-0.26)\end{array}$ & $\begin{array}{c}-0.06 \\
(-0.26)\end{array}$ & $\begin{array}{c}-0.12 \\
(-0.47)\end{array}$ & $\begin{array}{c}-0.06 \\
(-0.24)\end{array}$ \\
\hline Age & $\begin{array}{c}-0.06 \\
(-0.17)\end{array}$ & $\begin{array}{c}-0.13 \\
(-0.38)\end{array}$ & $\begin{array}{c}-0.09 \\
(-0.24)\end{array}$ & $\begin{array}{c}-0.17 \\
(-0.44)\end{array}$ & $\begin{array}{c}-0.05 \\
(-0.13)\end{array}$ & $\begin{array}{c}0.09 \\
(0.24)\end{array}$ \\
\hline Gender & $\begin{array}{c}0.09 \\
(0.43)\end{array}$ & $\begin{array}{c}0.08 \\
(0.37)\end{array}$ & $\begin{array}{c}0.15 \\
(0.68)\end{array}$ & $\begin{array}{c}0.15 \\
(0.68)\end{array}$ & $\begin{array}{c}0.34 \\
(1.46)\end{array}$ & $\begin{array}{c}0.36 \\
(1.54)\end{array}$ \\
\hline NGO & $\begin{array}{c}0.45 \\
(1.41)\end{array}$ & $\begin{array}{c}0.46 \\
(1.42)\end{array}$ & $\begin{array}{c}-0.22 \\
(-0.82)\end{array}$ & $\begin{array}{c}-0.19 \\
(-0.62)\end{array}$ & $\begin{array}{c}1.35^{* * *} \\
(3.03)\end{array}$ & $\begin{array}{c}1.35^{* * *} \\
(2.96)\end{array}$ \\
\hline
\end{tabular}

Notes:

$* * *(* *, *)$ means that the appropriate explanatory variable has an effect at the $1 \%(5 \%, 10 \%)$ level of significance.

Number of observations = 159 in (1), number of observations = 156 in (2), number of observations = 157 in (3), and (5), number of observations $=154$ in (4) and (6). 
Table 10: Maximum likelihood estimates (z-statistics) in ordered probit models, determinants of the desired degree of incorporation of equity rules in future international climate agreements, short-term time horizon, dependent variable: "Degree" (for the ability-to-pay, the poor losers, and the stand alone rule)

\begin{tabular}{|l|c|c|c|c|c|c|}
\hline Explanatory & $(1)$ & $(2)$ & $(3)$ & $(4)$ & $(5)$ & $(6)$ \\
variables & $\begin{array}{c}\text { Ability- } \\
\text { to-pay }\end{array}$ & $\begin{array}{c}\text { Ability- } \\
\text { to-pay }\end{array}$ & $\begin{array}{c}\text { Poor } \\
\text { losers }\end{array}$ & $\begin{array}{c}\text { Poor } \\
\text { losers }\end{array}$ & $\begin{array}{c}\text { Stand } \\
\text { alone }\end{array}$ & $\begin{array}{c}\text { Stand } \\
\text { alone }\end{array}$ \\
\hline G77/China & $\begin{array}{c}-0.08 \\
(-0.48)\end{array}$ & -- & $\begin{array}{c}0.43^{* *} \\
(2.19)\end{array}$ & -- & $\begin{array}{c}0.01 \\
(0.03)\end{array}$ & - \\
\hline GDP per capita & -- & $-0.13^{*}$ & -- & $\begin{array}{c}-0.20^{* *} \\
(-2.47)\end{array}$ & -- & 0.01 \\
\hline COP & $\begin{array}{l}-0.15 \\
(-0.84)\end{array}$ & $\begin{array}{c}-0.05 \\
(-0.28)\end{array}$ & $\begin{array}{c}0.20 \\
(1.04)\end{array}$ & $\begin{array}{c}0.27 \\
(1.38)\end{array}$ & $\begin{array}{c}-0.17 \\
(-0.95)\end{array}$ & $\begin{array}{c}-0.14 \\
(-0.79)\end{array}$ \\
\hline Social science & $\begin{array}{c}0.08 \\
(0.32)\end{array}$ & $\begin{array}{c}0.13 \\
(0.55)\end{array}$ & $\begin{array}{c}0.15 \\
(0.56)\end{array}$ & $\begin{array}{c}0.16 \\
(0.59)\end{array}$ & $\begin{array}{c}0.10 \\
(0.38)\end{array}$ & $\begin{array}{c}0.11 \\
(0.41)\end{array}$ \\
\hline Age & $\begin{array}{c}0.01 \\
(0.02)\end{array}$ & $\begin{array}{c}-0.02 \\
(-0.05)\end{array}$ & $\begin{array}{c}-0.93^{* *} \\
(-2.46)\end{array}$ & $\begin{array}{c}-1.08^{* * *} \\
(-2.94)\end{array}$ & $\begin{array}{c}-0.72^{*} \\
(-1.74)\end{array}$ & $\begin{array}{c}-0.71^{*} \\
(-1.66)\end{array}$ \\
\hline Gender & $\begin{array}{c}0.16 \\
(0.68)\end{array}$ & $\begin{array}{c}0.14 \\
(0.62)\end{array}$ & $\begin{array}{c}0.14 \\
(0.68)\end{array}$ & $\begin{array}{c}0.07 \\
(0.33)\end{array}$ & $\begin{array}{c}-0.03 \\
(-0.10)\end{array}$ & $\begin{array}{c}-0.02 \\
(-0.06)\end{array}$ \\
\hline NGO & $\begin{array}{c}0.04 \\
(0.16)\end{array}$ & $\begin{array}{c}0.05 \\
(0.16)\end{array}$ & $\begin{array}{c}-0.49 \\
(-1.52)\end{array}$ & $\begin{array}{c}-0.58^{*} \\
(-1.74)\end{array}$ & $\begin{array}{c}0.07 \\
(0.25)\end{array}$ & $\begin{array}{c}0.08 \\
(0.28)\end{array}$ \\
\hline
\end{tabular}

\section{Notes:}

$* * *(* *, *)$ means that the appropriate explanatory variable has an effect at the $1 \%(5 \%, 10 \%)$ level of significance.

Number of observations $=153$ in (1), number of observations = 150 in (2), number of observations $=157$ in (3), number of observations = 155 in (4), number of observations = 142 in (5), number of observations = 139 in (6). 
Table 11: Maximum likelihood estimates (z-statistics) in ordered probit models, determinants of the desired degree of incorporation of equity rules in future international climate agreements, long-term time horizon, dependent variable: "Degree" (for the egalitarian, the sovereignty, and the polluter-pays rule)

\begin{tabular}{|l|c|c|c|c|c|c|}
\hline & $(1)$ & $(2)$ & $(3)$ & $(4)$ & $(5)$ & $(6)$ \\
$\begin{array}{l}\text { Explanatory } \\
\text { variables }\end{array}$ & Egalitarian & Egalitarian & $\begin{array}{c}\text { Sove- } \\
\text { reignty }\end{array}$ & $\begin{array}{c}\text { Sove- } \\
\text { reignty }\end{array}$ & $\begin{array}{c}\text { Polluter- } \\
\text { pays }\end{array}$ & $\begin{array}{c}\text { Polluter- } \\
\text { pays }\end{array}$ \\
\hline G77/China & $\begin{array}{c}-0.40^{* *} \\
(-2.21)\end{array}$ & -- & $\begin{array}{c}0.02 \\
(0.10)\end{array}$ & -- & $\begin{array}{c}0.25 \\
(1.30)\end{array}$ & - \\
\hline GDP per capita & -- & $\begin{array}{c}0.12 \\
(1.53)\end{array}$ & -- & $\begin{array}{c}-0.11 \\
(-1.46)\end{array}$ & -- & $-0.16 *$ \\
\hline COP & $\begin{array}{c}0.16 \\
(0.88)\end{array}$ & $\begin{array}{c}0.24 \\
(1.27)\end{array}$ & $\begin{array}{c}-0.23 \\
(-1.23)\end{array}$ & $\begin{array}{c}-0.13 \\
(-0.68)\end{array}$ & $\begin{array}{c}-0.12 \\
(-0.62)\end{array}$ & $\begin{array}{c}-0.10 \\
(-0.48)\end{array}$ \\
\hline Social science & $\begin{array}{c}-0.17 \\
(-0.67)\end{array}$ & $\begin{array}{c}-0.19 \\
(-0.73)\end{array}$ & $\begin{array}{c}-0.57^{* *} \\
(-2.40)\end{array}$ & $\begin{array}{c}-0.54 \\
(-2.23)\end{array}$ & $\begin{array}{c}-0.18 \\
(-0.65)\end{array}$ & $\begin{array}{c}-0.13 \\
(-0.48)\end{array}$ \\
\hline Age & $\begin{array}{c}-0.25 \\
(-0.67)\end{array}$ & $\begin{array}{c}-0.35 \\
(-0.96)\end{array}$ & $\begin{array}{c}-0.03 \\
(-0.09)\end{array}$ & $\begin{array}{c}-0.11 \\
(-0.31)\end{array}$ & $\begin{array}{c}-0.34 \\
(-0.97)\end{array}$ & $\begin{array}{c}-0.25 \\
(-0.71)\end{array}$ \\
\hline Gender & $\begin{array}{c}0.09 \\
(0.40)\end{array}$ & $\begin{array}{c}0.09 \\
(0.37)\end{array}$ & $\begin{array}{c}0.12 \\
(0.57)\end{array}$ & $\begin{array}{c}0.10 \\
(0.49)\end{array}$ & $\begin{array}{c}0.09 \\
(0.40)\end{array}$ & $\begin{array}{c}0.10 \\
(0.42)\end{array}$ \\
\hline NGO & $\begin{array}{c}0.03 \\
(0.08)\end{array}$ & $\begin{array}{c}0.07 \\
(0.18)\end{array}$ & $\begin{array}{c}0.41 \\
(1.34)\end{array}$ & $\begin{array}{c}0.40 \\
(1.30)\end{array}$ & $\begin{array}{c}0.34 \\
(0.85)\end{array}$ & $\begin{array}{c}0.31 \\
(0.76)\end{array}$ \\
\hline
\end{tabular}

\section{Notes:}

$* * *(* *, *)$ means that the appropriate explanatory variable has an effect at the $1 \%(5 \%, 10 \%)$ level of significance.

Number of observations $=158$ in (1), number of observations = 155 in (2), number of observations = 157 in (3) and (6), number of observations $=154$ in (4), number of observations $=160$ in (5). 
Table 12: Maximum likelihood estimates (z-statistics) in ordered probit models, determinants of the desired degree of incorporation of equity rules in future international climate agreements, long-term time horizon, dependent variable: "Degree" (for the ability-to-pay, the poor losers, and stand alone rule)

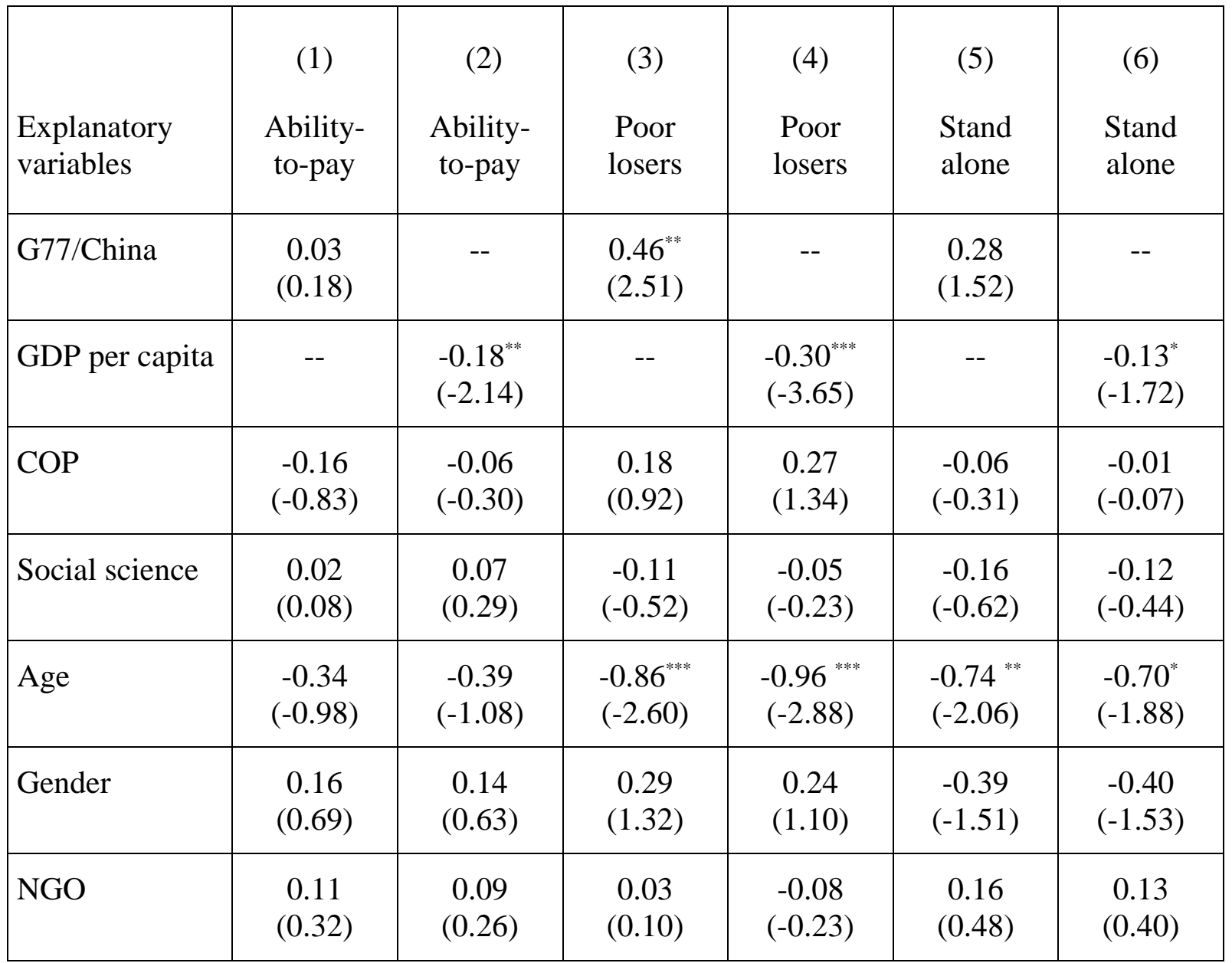

Notes:

$* * *(* *, *)$ means that the appropriate explanatory variable has an effect at the $1 \%(5 \%, 10 \%)$ level of significance.

Number of observations = 157 in (1), number of observations = 154 in (2), number of observations = 159 in (3), number of observations = 156 in (4), number of observations = 146 in (5), number of observations = 143 in (6). 